\title{
Phenothiazines as efficient redox mediators for dye-decolorization at neutral / alkaline pH by bacterial laccases
}

\author{
Lucy Coria-Oriundo ${ }^{1}$, Fernando Battaglini ${ }^{1}$, and Sonia Wirth $^{2}$ \\ ${ }^{1}$ Instituto de Química Física de los Materiales Medio Ambiente y Energía \\ ${ }^{2}$ Universidad de Buenos Aires Facultad de Ciencias Exactas y Naturales
}

September 11, 2020

\begin{abstract}
Laccases are oxidoreductases with the outstanding ability to oxidize phenolic and non-phenolic substrates coupled to the reduction of $\mathrm{O} 2$ to $\mathrm{H} 2 \mathrm{O}$. Among them, bacterial enzymes are suitable biocatalysts for application in industrial processes under harsh conditions. However, to be active on high redox potential substrates, bacterial laccases requires of redox mediators: electron carriers between the laccase and other compounds not directly oxidizable by the enzyme. Here we demonstrate that $\beta$-(10-phenothiazyl)-propionic acid can be used as an efficient and low-cost redox mediator for decolorization of synthetic dyes by bacterial laccases. Using this laccase-mediator system, more than $80 \%$ of Indigo Carmine and Malachite Green decolorization was reached after $1 \mathrm{~h}$ or $2 \mathrm{~h}$ of incubation, respectively, both at $\mathrm{pH} 8$ and in tap water ( $\mathrm{pH} 6.8$ ). Furthermore, more than $40 \%$ of Remazol Brilliant Blue R and $80 \%$ of Xylidine ponceau were decolorized after $5 \mathrm{~h}$ at $\mathrm{pH} 8$ and $50^{\circ} \mathrm{C}$. In addition, we showed this system supports at least 3 decoloration cycles without loss of activity, representing a promising biological process for cost-effective and environmentally friendly decolorization and degradation of synthetic dyes and for other industrial applications of laccases requiring neutral or alkaline $\mathrm{pH}$.
\end{abstract}

\begin{abstract}
Laccases are oxidoreductases with the outstanding ability to oxidize phenolic and non-phenolic substrates coupled to the reduction of $\mathrm{O}_{2}$ to $\mathrm{H}_{2} \mathrm{O}$. Among them, bacterial enzymes are suitable biocatalysts for application in industrial processes under harsh conditions. However, to be active on high redox potential substrates, bacterial laccases requires of redox mediators: electron carriers between the laccase and other compounds not directly oxidizable by the enzyme. Here we demonstrate that $\beta$-(10-phenothiazyl)-propionic acid can be used as an efficient and low-cost redox mediator for decolorization of synthetic dyes by bacterial laccases. Using this laccase-mediator system, more than $80 \%$ of Indigo Carmine and Malachite Green decolorization was reached after $1 \mathrm{~h}$ or $2 \mathrm{~h}$ of incubation, respectively, both at $\mathrm{pH} 8$ and in tap water $(\mathrm{pH}$ 6.8). Furthermore, more than $40 \%$ of Remazol Brilliant Blue R and $80 \%$ of Xylidine ponceau were decolorized after $5 \mathrm{~h}$ at $\mathrm{pH} 8$ and $50^{\circ} \mathrm{C}$. In addition, we showed this system supports at least 3 decoloration cycles without loss of activity, representing a promising biological process for cost-effective and environmentally friendly decolorization and degradation of synthetic dyes and for other industrial applications of laccases requiring neutral or alkaline $\mathrm{pH}$.
\end{abstract}

